\title{
ТИПовІ РИСИ НОМо VIRTUALIS У ВІРТУАЛІЗОВАНОМУ ІНФОРМАЦІЙНОМУ СУСПІЛЬСТВІ
}

\section{С.В. Марійко}

Віртуалізація різних сфер сучасного суспільства проходить через свідомість кожної людини, трансформуе їі, формуе новий світогляд, ціннісні орієнтаціі, по суті створюе нові умови існування. Віртуалізація суспільства детермінуе появу людини віртуальної як нового соціального типу особистості, котра сприймае нові умови поліонтичного світу, використовуе сучасні технологічні інновації для творення віртуальних реальностей та активно проживає життя у світі віртуальних образівмaсок.

3 такої точки зору особистість розглядається у межах теорії масок як множинна та мінлива. Отже, homo virtualis являе собою людину-маніпулятора створеними нею образами, яка піддалась спокусі симуляції та ілюзорності. Використаємо даний підхід і для нашого дослідження, метою якого $є$ аналіз homo virtualis як феномену віртуалізованого інформаційного суспільства, вивчення її типових рис та характеристик.

Першочергово, спробуємо дати визначення людині віртуальній, оскільки статус її існування наразі залишається невизначеним. На думку С. Хоружого [8], homo virtualis - людина, замкнута у горизонті віртуальної реальності, що живе за 111 специфічними законами та виробляє віртуалістські стереотипи поведінки (які полягають у маніпулюванні вже готовими формами і культурними кодами). 3 точки зору М. Носова [7], відповідно до постулату іманентності, згідно з яким людина належить до того світу, в котрому вона діє, котрий вона сприймає i переживає, людина віртуальна стає такою тоді, коли вона створює

Актуальні проблеми духовності:

Зб. наук. праць / Ред.: Я.В. Шрамко

Вип. 11. - Кривий Ріг, 2010, 245-251 245

ISSN 2076-7382 
віртуальний світ, поринае в нього та діе згідно 3 його принципами. Homo virtualis можна означити тільки охарактеризувавши три варіанти описання віртуальної реальності, відповідно до яких віртуальна людина - це:

- людина, яка використовуе комп'ютерні моделі тілесної реальності і живе у створеному нею за допомогою техніки «дзеркальному світі» (комп'ютерна віртуальна реальність);

- людина, якій одвічно притаманне творення символічних реальностей (власне віртуальна реальність);

- або людина, котра перебуває у специфічному віртуальному стані (стан віртуального користувача).

Таким чином, homo virtualis слід визначати як творця ймовірнісних, потенційних реальностей (з огляду на одвічно існуючу, притаманну їй віртуальність), що активно використовуе для цього технічні засоби дигітального та інтерактивного середовища інформаційного віртуалізованого суспільства сучасності та усвідомлюе умовність, ілюзорність віртуальної реальності. Особисті якості віртуальної людини розкриватимуться, відповідно, через самоусвідомлення та самоідентифікацію всередині віртуальної реальності.

По-друге, слід відзначити амбівалентність впливу віртуальної реальності на людину. 3 одного боку, очевидним $є$ те, що творення віртуальних світів е способом самореалізації особистості, з іншого - специфіка віртуальної реальності впливае на внутрішній світ людини та трансформуе її життеві орієнтири.

Спробуемо визначити типові риси homo virtualis як феномену віртуалізованого інформаційного суспільства сучасності. Специфічною рисою людини віртуальної є ігровий характер поведінки, грайливість у спілкуванні, електронному листуванні, викликана легким та поверхневим сприйняттям варіативної дійсності. Карнавалізація, гра, маскування є невід'ємною рисою віртуального життя, адже маска дозволяє уникнути відчуття екзистенційного вакууму, допомагає людині відповідати шаленому ритму змін, який диктує реальний світ. Людина потребує маскування як захисту від відчуття власної розмитої ідентичності, вона створюе архів образів, які дозволяють кожного разу грати необхідну роль, відтак втрачаючи реальну власну самість. Маска $\epsilon$ «форма гри 3 життям, коли життя переграє актора» [5, с.7], вона $€$ 
формою захисту від реальності та водночас формуе власну реальність, що дозволяе уникнути програвання повсякденних соціальних ролей.

Homo virtualis має розширені можливості ідентифікації, може наділяти свій образ будь-яким набором характеристик. Така ідентичність множинна, адже людина може використовувати пілу галерею образівмасок одночасно. «Внутри сцены субъективного представления мелькает и, естественно, оценивается целый калейдоскоп сменяющих друг друга образов, фрагментизируя субъекта» [6, с.53]. Відносини між віртуальним образом-маскою та її творцем - реальною людиною амбівалентні. 3 одного боку, вони грунтуються на ототожненні реальної людини з створеним нею образом, з іншого - самообраз-маска відособлений від творця та існуе фактично незалежно від нього i homo virtualis являє собою чергову личину, наділену за волею іï творця реальними або бажаними рисами. Віртуальна людина - володар масок опиняеться у ситуації втрати істинної ідентичності, її дефрагментації (реальна людина дифрактує у множину мініатюрних его-самообразів). Конфігуративість ідентичності (її ситуативність, використання маски-самообразу залежно від варіанту подій) пов'язана 3 неможливістю тривалого перебування у котромусь із статусів, бо «перспектива обретения ,стабильного пристанища" в конце дороги отсутствует; быть в пути стало постоянным образом жизни индивидов, не имеющих (теперь уже хронически) своего устойчивого положения в обществе» $[1$, с. 184]. Це підтверджуе думку російських дослідниць О. Белінської та А. Жичкіної [2], які звертають увагу на новий соціонормативний канон людини, для якої момент набуття справжньої ідентичності-це момент відмови від вже встановленого на користь нового. Узагальнюючи вищезазначене, підсумуємо, що людина віртуальна втрачає такі атрибути особистості як стабільна самоідентифікація та соціальний статус, а натомість формуе розмиту, мінливу (ситуативну), конфігуративну ідентичність.

Нагальною потребого для віртуальної людини $е$ перебування у центрі уваги, наявність відчуття популярності та необхідності. Саме це бажання визначає прагнення бути високо оціненим іншими, цікавим співрозмовником, корисним порадником і саме воно визначає необхідність наповнювати свій образ бажаними характеристиками. Реальна людина, залежна від статусу, соціальної ролі та освітнього рівня, не може бути настільки цікавою, звабливою та популярною і тому вона піддається спокусі симуляції, створюючи численні самообрази-маски. у віртуальному просторі, де особистісний статус детермінований рольовою ефективністю та успішністю обраної ролі, потреба створюва- 
ти галерею образів е першочерговою. Продовжимо думку 3. Баумана, «клубной картой становится умение „позиционировать“ себя в переплетении возможностей, а не оставаться парализованным одной пожизненной специальностью» $[1$, с. 50], а також тілом, статусом, роллю.

Віртуальна людина надзвичайно активна та діяльна, адже саме її творчий акт породжує «дзеркальний світ» віртуальної реальності, численні самообрази та спричиняе комунікативні акти. Активна творча позиція людини є необхідною та визначальною у комп'ютерному віртуальному просторі, вона викликана потягом, волею до віртуальності, спокусою симуляції реальності. Невід'ємною рисою життя homo virtualis стає швидкість та операціональність, радісна спонтанність та варіативність. Сучасна людина, на думку 3. Баумана, орієнтована на короткостроковість, тимчасовість і мінливість, вона байдужа до довготривалих планів. Віртуальна людина мусить відповідним чином реагувати на постійно змінні потоки інформаціі, уміти складати калейдоскопічні частини мозаїки кодів та символів, саме тому відбувається поступова трансформація її ціннісних орієнтацій у бік недовговічності, швидкості та мінливості. Невипадково нині найпопулярнішою формою візуального мистецтва $є$ інсталяції (на кшталт робіт Д. Херста), а бріколаж перетворюється на спосіб самовираження та стає світоглядним принципом цитатного, закодованого та швидкоплинного спілкуваннятворчості.

Типовою рисою людини віртуальної є акцент на прозорості та демонстративності, оскільки домінуючим є бажанням перебувати у центрі уваги публіки, бути популярним, цікавим, певною мірою впізнаваним «брендом». Саме така потреба викликае необхідність створювати ряд привабливих для інших образів та ідентичностей, адже власна нестійка та дефрагментована ідентичність, майже загублена у просторі ретельно створених самообразів зазвичай не $\boldsymbol{\varepsilon}$ настільки принадною, різнобічно розвиненою та популярною, щоб зацікавити велику аудиторію. Однак таку демонстративність можна назвати псевдопрозорістю та квазіпублічністю, оскільки реальні життеві факти реальної особистості зазвичай не стають загальновідомими, натомість демонструється інсталяція, симулякр справжнього життя, один з її самообразів (що відповідатиме ситуації та обраному на даний момент іміджу). Адже особливістю віртуальної людини, що має конфігуративну ситуативну ідентичність $є$ можливість абсолютного управління враженнями про себе. Саме тому демонстративне виставляння напоказ інтимних подробиць та побуту відбувається у режимі «покажу те, що всі хочуть бачити і що позитивно впливатиме на мій іміджљ. 
Людина віртуальна перебувае у ситуації зміни статусу тілесності. Тілесність як така стає непотрібною, адже віртуальна комунікація $\mathbf{e}$ комунікацією образів і навіть згадка про тіло іншої людини стає зайвою. Створення комп'ютерної віртуальної реальності як псевдотілесної ïi моделі по суті відкидае людську тілесність як непотрібну. Людина має справу не з реально існуючими іншимим людьми, а з їх образами, віртуальними моделями, які вона бачить лише на екрані і тому не може бути впевнена у їх реальності (істинна особистість віртуального співбесідника є невловимою). Спілкуючись у мережі, проблематичною стае навіть думка про тіло як про фізичну сутність, адже воно стае сутнісним на екрані. Аналогічно трансформується уявлення і про власне тіло - віртуальність особистості неминуче викликає відчуження, дистанціювання від свого реального тіла та статусу. А.Крокер та М.Вейнстайн також звертають увагу на відчуження людини від плоті у процесі користування комп'ютерами. Тим не менше, людина віртуальна має реальне тіло та мусить повертатись до нього 3 простору віртуальної реальності, що у свою чергу викликае дискомфорт та дегармонізацію її сприйняття віртуальності як свого життевого світу. Слід звернути увагу і на той факт, що дистанціювання від реального тіла породжуе бажання створити віртуальне. Оскільки кожен може виробити власний образ-персонаж з заданими характеристиками (статтю, віком, тілом), вийти за межі наявного, то тіло розглядається вже скоріше як об'єкт управління, а не як невід'ємна частина особи, адже «виртуальные тела можно иметь в великом множестве и менять их в любое время» $[3$, с. 159$]$.

Віртуальна людина полінімна та псевдонімна, адже у віртуалізованому інформаційному просторі запускається механізм поступової втрати власного імені на користь маніпуляції черговим nick-name. Згідно з поглядами 3. Баумана, індивідуальність сучасної людини можна порівняти хіба що з множиною моментальних знімків, вона конфігуративна та мінлива, саме тому homo virtualis бажає мати численні варіації власного імені, під якими приховується черговий самообраз-маска. Анонімність/полінімність слід сприймати як приховування власного справжнього імені (а також, відповідно, реального статусу та соціальної ролі), як певний зв'язок між реальною і онлайновою віртуальною особистістю. Така можливість залишатись анонімним (не підписуватись власним іменем)/полінімним (використовувати одне із численних вигаданих імен) реалізуе свободу, дозволяе залишити повсякденні соціальні ролі та обов'язки, звільняе від відповідальності за порушення рольових очікувань та створює ілюзію всесильності і вседозволеності. 
«Людям предлагается (скорее даже навязывается) беспрецедентная свобода, но ее ценой становится столь же беспрецедентная неуверенность» $[1$, с. 201], адже тепер кожна людина, поринаючи у віртуальну реальність (також у певній масці і під певним nickoм) абсолютно невпевнена у тому, що спілкується $з$ реальною людиною, а не з такою ж маскою-образом.

Слід також відмітити специфіку світосприйняття людини віртуальної, яке стає образним, кліповим, мозаїчним. Homo virtualis сама створюе логічний ланцюг суджень, подій, новин, вибудовує конструкції на основі бліц-інформації. Сприйняття реальності відбувається у фреймовому режимі, оскільки фрейм визначає наше бачення світу та реакцію на певні ситуації. Людина, маючи у пам'яті фрейми як орієнтовні структури, може заповнювати їх варіативні складові таким чином, щоб мати алгоритм дії для будь-якої ситуації. Фрейм є моделлю знань, котра активізуеться у певній ситуації і слугуе для її пояснення i передбачення. Фреймове сприйняття світу дає можливість швидко орієнтуватись у інформаційних джерелах, вибудовувати на основі заданих структур нові знання, та відповідним чином реагувати на поліваріантні події. Не можна не погодитись з думкою В. Косихіна, що «мышление, как продумывание, неспешное проникновение в суть сменяется мышлением, как техникой манипуляции с информационными единицами» $[6$, с. 54]. Експоненціальне збільшення каналів інформації, потоків кодів і смислів потребують швидкої реакції та оперативності, саме тому фреймова модель світосприйняття дозволяє використовувати наявні знанневі конструкції та оперативно переорієнтовуватись у сучасному мінливому світі.

Специфіку світосприйняття людини віртуальної можна означити за допомогою терміну бріколаж. Адже сучасна людина є майстром, що перекодовуе, трансформуе, нашаровуе нові смисли, нові тексти, на основі вже існуючих. Бріколаж нагадує калейдоскоп, компоненти якого змінюються механічно, не деформуючи змісту картинки. Віртуальна людина перекодовуе смисли, створюе нову реальність, використовуючи підручний матеріал традицій, звичаїв, правил, слів, уявлень. Надаючи у новому контексті інший смисл знайомим цитатам, висловлюванням, автор перетворюе їх так, що для читача (іншого) смисл, який він отримуе, виявляеться залежним від його власної уяви. Таким чином, характерними для комунікації та творчості сучасної людини е цитатність, фрагментарність, принцип монтажу та маніпулювання кодами.

Узагальнюючи вищесказане, зазначимо, що віртуальна реальність 
впливає на характер суспільства, генеруючи новий тип сопіокультурної реальності, новий тип соціального індивіда. Homo virtualis - це людина, орієнтована на віртуальність, вона $є$ творцем та носієм віртуальної культури, а основні соціальні та культурні потреби задовольняе у створеному віртуальному світі. Homo virtualis притаманні такі риси: конфігуративна ідентичність, зміна статусу тілесності, дистанціювання від реальних соціальних ролей, активність, квазіпублічність, специфічне світосприйняття (бріколаж та фрейм як форми сприйняття реальності). Віртуальна людина є набором соціальних ролей, котрі вона «ррає» та численних самообразів-масок, кожен 3 яких наділений бажаними характеристиками реальної особистості; справжньою для неї $\epsilon$ «игра с условностями, создание новых уровней фикции, размывание граней между реальностью и выдумкой» $[4$, с. 144].

\section{1 Бібліографія}

[1] Бауман 3. Индивидуализированное общество.- М.: Логос, 2002.

[2] Белинска.я E., Жичкина А. Стратегии самопрезентации в Интернет и их связь с реальной идентичностью. Інтернет-ресурс, режим доступу - http://www.flogiston.ru/projects/articles/strategy.shtml.

[3] Беляев B.A. Антропология техногенной цивилизации на перекрестке позиций. - М.: ЛКИ, 2007.

[4] Вейз Дю.. Э. Времена постмодерна: христианский взгяд на современную мысль и культуру. - М.: Фонд «Лютеранское наследие», 2002.

[5] Корабльова Н.С. Багатомірність рольової реальності: ролі і маски - лик і личина. - Харків: ХНУ, 2000.

[6] Косыхин В.Г. Информационное общество и субъект эпохи постмодерна // Информационная цивилизация: пространство, культура, человек (под ред. В.Б. Устьянцева). - Саратов: Издательство Поволжского межрегионального учебного центра, 2000. - С. 53-55.

[7] Носов Н.А. Виртуальная психология. - М.: Аграф, 2000.

[8] Хоружий С.С. О старом и новом.-СПб.: Алетейя, 2000.

Надійила до редакцй 14 лтотого 2010 p. 